\title{
Malaria and Public Health Measures in Colonial Urban Zanzibar, 1900-1956
}

\author{
Amina Issa
}

\section{Environmental and Sanitary Engineering Campaigns}

$\mathrm{E}$ arly twentieth century environmental and sanitary engineering campaigns implicated three major areas in Zanzibar. As records from the Department of Medicine and Public Health and other administrative files from the Provincial Administration Department and Public Works Department show, they included the reclamation of the Creek and swampy ground. The filling of natural depressions caused by quarrying works started from 1930. These measures were a response to the growing medical understanding that malaria was spread by mosquitoes.

From the early twentieth century, Zanzibar decided to embark on anti-malarial campaigns which focussed on controlling both Anopheles gambiae and A. funestus. These two malaria species bred in swamps, banks of rivers, potholes, shallow depressions, in hoof-prints of cattle, earthen jars, sailing boats, canoes, lighters, borrow-pit and flooded rice-fields. In 1913, the Colonial Office sent Professor W. J. Ritchie Simpson, a British physician and a pioneer in tropical medicine, to visit British colonies in East Africa. Simpson, who formerly worked as a health officer for Calcutta, India in the 1890s and was a founder of the Journal of Tropical Medicine in 1898, was from 1913 an advisor of the Secretary of State for the Colonies on health matters. He visited Zanzibar, Kenya and Uganda to investigate health conditions, and to propose measures to be taken to improve health of the "native" population, (Indians, Arabs and Africans). 'Simpson's survey confirmed that mosquitoes bred during rainy seasons. He recommended to the Zanzibar authorities that they refill the Creek in order to stop epidemics.

The anti-malarial works that focused on reclamation of land and swamps had just started in the United States of America. Since the early 1900s, the United States had been involved in the campaigns against yellow fever in the Panama Canal area.

1 W. J. Simpson, Report on Sanitary Matters in East African Protectorate, Uganda and Zanzibar (London, 1915), pp. 4-5. 
In 1901, the famous and influential American physician William Crawford Gorgas established anti-yellow fever brigades in Havana, Cuba during the Spanish American War. The work had also involved controlling the breeding sites of anopheles mosquitoes. Gorgas, chief sanitary officer of the Panama Canal Commission between 1904 and 1913, eliminated the mosquito in the region of the canal and made possible the building of the Panama Canal. Gorgas 'sanitary squads' drained swamps and cleared out weeds, spreading a concoction of carbolic acid, resin and caustic soda. ${ }^{2}$ According to Philip Curtin, "the success of American public health officers in combating yellow fever in Cuba and Panama helped raise false hopes for mosquito control in Africa". In Tanganyika, German East Africa, the authorities recruited a malaria control specialist who had formerly worked in the malaria and yellow fever eradication campaigns in Panama, but the project was abandoned with the outbreak of the First World War. ${ }^{4}$

\section{The Reclamation of Creek}

The canalization of the Creek which separated Stone Town and Ng'ambo was proposed earlier by the medical and health authorities in Zanzibar. ${ }^{5}$ Lack of funds delayed the work. In the eyes of the Europeans who began visiting Zanzibar Town in the mid-nineteenth century, the Creek was more of a 'fetid lagoon', with all the dirt and drainage pollution that ran into it from the town. In 1897, the colonial authorities built embankments around the Creek for the use of the town population. Rev. W. K. Firminger of the Universities' Mission to Central Africa (UMCA), who was stationed in the town at that time, welcomed the decision to build the embankment. Informing William Trevars, Secretary of the UMCA, London, of the government's intention to do this, Firminger declared that "we shall now have a very considerable frontage towards the Creek, which if the Government carry out their intentions of making an embankment will become most valuable. It will improve the station greatly".

2 Gordon Harrison, Mosquitoes, Malaria and Man: A History of the Hostilities since 1880 (London, 1978), p. 161.

3 Philip Curtin, "Medical Knowledge and Urban Planning in Colonial Tropical Africa", in Steven Feierman and John Janzen eds., The Social Basis of Health and Healing in Africa (Berkeley, Los Angeles and Oxford, 1992), p. 241.

4 D. Ferguson, "The Political Economy of Health and Medicine in Colonial Tanganyika', in M. H. Y. Kaniki ed., Tanzania under Colonial Rule (London, 1980), pp. 307343, p. 331.

5 Zanzibar composes of two islands, Unguja and Pemba. The bigger Unguja Island is also sometimes refers as Zanzibar. Zanzibar Town which was the colonial administration center and located in Unguja Island was comprises of Stone Town and Ng'ambo (the Other Side).

6 Rhodes House Library (RHL), Mss. W. K. Firminger, Priest in Charge, Zanzibar, Box A1 VIII, p. 556. 
The filling-in of the Creek was not undertaken immediately as the matter was somewhat controversial and became a matter of debate among medical officers in Zanzibar. In 1914, soon after the departure of Simpson, Dr. Curwen, the Principal Health Officer (PHO) in Zanzibar wrote that "I think Professor Simpson is wrong in describing it [the Creek] as formerly being a breeding place for mosquitoes in the wet season; it was washed by salt water and too porous for rain water to lodge". Also, the medical and health officers in Zanzibar decided not to fill the Creek for drainage purposes. It was reported that "its tidal waters served to daily remove much offensive drainage that was discharged into creek".

Beginning in 1915, the reclamation work started at the southern part of the Creek at Mnazimmoja area. The embankment was constructed during the low tide in order to stop the sea water to flow again at Mnazimmoja ground. In 1918, excavations were made and a concrete open channel was laid down from the Mnazimmoja ground to the nearby wireless station. In 1919, Kikwajuni Road was built near the embankment. ${ }^{8}$ A portion of the nearby 'banjo' area had been reclaimed at the same period as the Mnazimmoja area. The photograph below shows the filling of the Creek at Darajani in 1943.

Figure 1. Filling of the Creek at Darajani in 1935

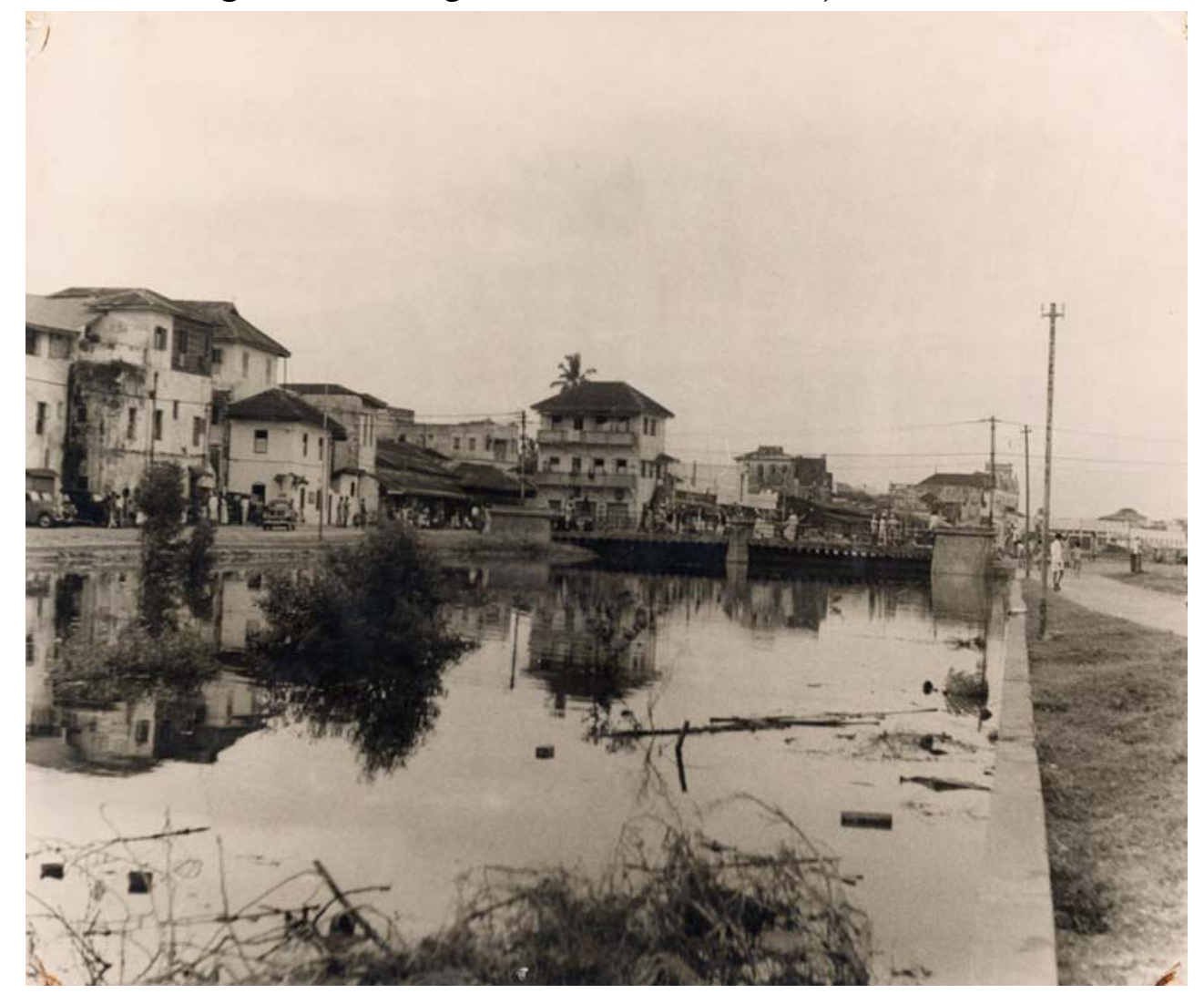

Source: ZNA AV 23/153, Darajani Bridge before the final reclamation of the Creek

7 Zanzibar National Archives (ZNA) AB 2/264, Professor W. J. Simpson, Report on the Sanitary Matters in the East Africa, Uganda and Zanzibar Protectorate, p. 73.

8 ZNA AE 2/748, Refusal of Access and Right of Way through Government Land at Kikwajuni to Khamisa Aloo Punja. 
It was only in 1935 that the serious works on the reclamation of the whole Creek for health and safety reasons had started. The new Director of Medical Services (DOMS), Dr. W. Leslie Webb, who had served in a medical post in Uganda before coming to Zanzibar, felt that it needed to be done. He regarded the Creek as a source of many diseases. The work of filling up was carried out by "putting refuse and a number of old flattened colas [concrete blocks] drums to form a sort of palisade at the base of the dump to keep the refuse in and to keep some of the water out". The work started at the west side of Hollis Road abutting on the premises of Peera Champsi. ${ }^{9}$ As late as 1956, refuse tipping continued at the southern part of the Creek above the Darajani Bridge.

Town people born in the early 1930s still remember the existence of the Creek. People used the ferry when it was high tide and crossed by foot when the tide was out. Salama Ali who lived in the Vikokotoni neighbourhood remembers how the Creek was at that time. She recalls that people living nearby were disturbed by mosquitoes which bred near the bank. What her grandmother did was simply to close the windows and doors of their house before sunset. She still remembers people's concern about the Creek filling project. Some people were happy as mosquito breeding was stopped. But other people who used the Creek to earn money by ferrying passengers were not happy.

The work of blocking up the Creek caused a lot of strife. The refuse that was used to fill the Creek attracted flies which then bred in the area. In 1938, a Miss Gunn from the UMCA complained to the medical authorities in Zanzibar about the smell that was caused by rotten refuse. She reported that the smell caused her a sore throat. ${ }^{11}$ Indeed, the Indian National Association (INA) registered their disapproval by sending a petition to the Government. Rustom Sidhwa, the Town Council representative from the INA sent a petition to the Sanitary Board. ${ }^{12}$ However, the work of filling the Creek continued as planned, although it was only in 1961 that the work came to an end south of the Hollis Bridge. A large area of the Creek north of the bridge at Funguni near the sea still remained to be filled and this was done later, after $1963 .{ }^{13}$ Generally, the reclamation work did a lot to restrain epidemics in the town. Nevertheless, it was rather a combination of several antimalarial measures which halted malaria, typhoid and cholera.

9 ZNA AJ 3/36, 'From DOMS to Provincial Commissioner, 19 May, 1935', Creek Filling in Re of.

10 Interview with Bi Salama Ali at Michenzani on 12 March, 2005.

11 ZNA AJ 3/36, 'Miss Gunn to DMS, 3 July, 1938', Creek Filling in Re of.

12 ZNA AJ 15/232, 'From R. Sidhwa to DOMS, 25 August, 1956', Disposal of Town Refuse. In 1957, after the formation of Afro-Shirazi Party (ASP), Rustom Sidhwa became one of its frontline leaders. According to Michael Lofchie some prominent Hindu merchants decided to join ASP to show their opposition and dislike of Oman Arabs landowners. See Norman Bennett, A History of the Arab State of Zanzibar (London, 1978).

13 ZNA AJ 15/134, Annual Report of Health Department, 1962-72. 


\section{Canalization of Streams and Swampy Areas}

The Canalization of streams and swampy areas was another malaria eradication strategy. For centuries swamps areas were connected with fever. James Webb explains that since first millennium BCE, the Romans had drained swamps in order to stop miasmatic diseases. The Abbasid Caliphate in the seventh century Iraq also reclaimed swamps in order to control fever. ${ }^{14}$ From 1902, Ronald Ross supported the reclamation of swamps and drainage as war against Anopheles gambiae and $A$. funestus, which prefer to breed on large swamps and on edges of swamps respectively.

Soon after the formation of the Anti-Mosquitoes Brigade in Zanzibar in 1907, the reclamation of the swampy areas started. Ziwani swampy area was given a priority during the early years of the twentieth century as the area was among the serious mosquitoes breeding site. By 1906, a police barrack and a dispensary for treating the local army and their families had already been constructed at the Ziwani area. Ditches were built to allow water from the swamp to flow in the tunnel outlets to the sea. ${ }^{15}$ Further canalization works at Ziwani area took place in 1910, after the passing of the '1909 Land Acquisition Decree' issued by F. R. Barton, the First Minister of Zanzibar. About 21.28 acres of land was acquired by the government for the drainage works. The Ziwani Swampy land was owned by the UMCA and the Comorian Community led by Mohamed Mlomri, Mohamed Salim and Jai Kari. They were given another piece of land at Kikwajuni following the introduction of the 'Compulsory Acquisition Act' which was passed in the same year. ${ }^{16}$

Similarly, in Tanganyika, during the Second World War, the British government employed the Royal Army Medical Corps to carry out anti-malarial works. The Corps concentrated on drainage, straightening of streams (to increase the flow of water), oiling of puddles, cleaning the banks of drains in order to facilitate the flow of predatory fish, and surveillance of livestock so that they would be kept far from streams and swamps. Livestock surveillance was aimed at preventing hoof prints in places that could offer conditions for mosquito breeding. ${ }^{17}$

Some people in Zanzibar reported to the Health Department that the filling of marshes caused substantial numbers of problems including soil erosion. In 1935, Bishop Heffernan of the UMCA wrote to the Director of Health arguing against the anti-malarial measures about to be introduced near the Mission area. The Bishop was critical of the decision to fill the well near the mission shamba plot at Kiinua Miguu, as he said it would create a water shortage. Also, he was worried that

14 James Webb, Humanity's Burden, A Global History of Malaria (Cambridge, New York, Madrid, Cape Town, Singapore, São Paulo and Delhi, 2009), p. 129.

15 ZNA AJ 29/243, 'From DMS to the Chief Secretary (CS), 10 June 1911,' AntiMalarial Drainage Schemes, Suggestions Re For.

16 ZNA AE 2/439, Acquisition of Land for Ziwani Swamp Drainage 1910 March - 1913, August

17 David Clyde, Malaria in Tanzania (London: Oxford University Press, 1967), p. 47. 
the drainage work near the shamba had caused problems of soil erosion. ${ }^{18}$ The canalization and filling of wells was however necessary in order to prevent malarial mosquitoes from breeding.

In 1944, growing of rice was prohibited in several swamps in Zanzibar Town, such as on the left of Fumba Road, near the Migombani valley, east side of Sebuleni Swamp, the area adjoining Mto Mpepo and between Saateni Bridge and the sea. This was enforced through, "The Public Health (Prevention of MosquitoBreeding) (Amendment)" Decree of 1944 which stated that "without the written authority of the $\mathrm{MOH}$ first hand and obtained, no person shall plant or cause to be planted rice, or prepare a land for the planting of rice, within a radius of three miles of the General Post Office (at Shangani) in the town of Zanzibar". ${ }^{19}$ As a result, people around these areas had to rely more on imported polished rice as a substitute to the local grown rice for their subsistence.

\section{Contributions of Malaria Research Officer (MRO)}

The post of Malaria Research Officer (MRO) was introduced in 1934, in an attempt to control malaria in Zanzibar. The colonial government in Zanzibar applied for the funds from the Colonial Development Funds (CDF) to sponsor the malaria survey which started in that year. Dr. McCarthy, a Senior Medical Officer (SMO) was appointed as the first MRO to investigate malaria problems in Zanzibar Town and adjoining areas. ${ }^{20}$ In 1929, Captain Sydney Price James, a former medical officer in Indian Medical Services (IMS) between 1897 and 1914, suggested for the appointment of a malariologist to investigate malaria problems in East Africa. In 1914, James had been appointed as an advisor on tropical diseases at the Ministry of Health in London after his retirement from IMS services. ${ }^{21}$

In Zanzibar, the MRO concentrated on ascertaining the "splenic index" in and about the town and determining the parasitic infestation indices. The "splenic index" was done through checking the human spleen in order to understand the acuteness of malaria. Normally, enlarged spleens were noticed among those children who were exposed to malaria infection. The MRO was also responsible for investigating all actual and potential mosquito breeding places in and near the town and for the typing of the various anopheline which were found in the area. He was involved in investigating the infection rates of the various species of mosquitoes and

18 ZNA AJ 29/243, 'From Bishop Heffernan to DMS, 29 April, 1935', Anti-Malarial Drainage Schemes, Suggestions Re For.

19 ZNA AB 2/331 The Public Health (Prevention of Mosquito-Breeding) Rules, 1935 and The Public Health (Prevention of Mosquito- Breeding) (Amendment)" Decree of 1944

20 ZNA AB 58/29, 'From British Residence to CS, 8 May, 1934', Colonial Development Fund, 1930-1949.

21 Captain S. P. James had published several works on mosquito taxonomy between 1901 and 1934. He had conducted research on the causation and prevention of malarial fevers and wrote reports for the prevention and treatment of malaria for health care providers. 
considering statistical evidence with regard to the correlation of the malaria problem with meteorological conditions, vital statistics and sociological circumstances. ${ }^{22}$ In 1935, Dr. McCarthy reported to the Chief Secretary of the State in Zanzibar that the survey progressed smoothly. ${ }^{23}$

The MRO reported that malaria infections were chiefly conveyed by A. gambiae and to a lesser degree by A. funestus as it had been pointed earlier by Dr. Mansfield-Aders. Dr. McCarthy explained that both types of mosquitoes bred freely all the year round in permanent swamps and streams outside the town boundary. The boundary was roughly one and half miles east of the Shangani Post office and one mile from the main part of the town. He further reported that during the dry season adult anopheline mosquitoes were found only in the areas adjacent to the above mentioned permanent breeding grounds. Anopheline infestation had been found to decrease in the town as the distance from the town boundary increases. The anopheline infectivity rate increased in the town proportionately with the distance from the boundary. ${ }^{24}$

From 1935 onward, a special anti malaria gang under the supervision of Dr. McCarthy was involved in many new programmes that aimed to control malaria in Zanzibar. All owners of land had been requested to clear the bushes and tall grass. This applied to graveyard areas as well. Notice was delivered by the MRO during Masika or heavy rain season and reminded the people that it was an offence to keep premises, estates, gardens or shamba, plots of land in such a state that unprotected water was allowed to stand and so enable mosquitoes to breed. Leaflets and posters, which indicated measures to be taken by householders, were posted in many areas. The leaflets notified that malaria mosquitoes bred in stagnant water, such as jars, tanks and holes which were excavated for planting trees. The leaflets also instructed that no bottles, whole or broken, tins, broken pieces of earthenware, coconut shells or seashells, calabashes and scrap metal were to be kept lying in the houses' compounds. ${ }^{25}$

The MRO furthermore recommended that quarrying for rock within the Zanzibar Town boundary and for two miles beyond was to be prohibited and that the keeping and grazing of cattle in the town area should be forbidden. He advised too on the formulation of schemes for the better drainage of low lying areas and the extension of the piped water supply to certain parts of Ng'ambo to allow shallow wells to be filled in. ${ }^{26}$ In 1935, the Colonial Development Funds (CDF) sponsored

22 ZNA AJ 1/37, 'From Dr. McCarthy to CS, 18 November, 1934', Anti-Malarial Measures, Zanzibar.

23 ZNA AJ 1/37, 'From Dr. McCarthy to CS, 7 March, 1935', Anti-Malarial Measures, Zanzibar.

24 ZNA AJ 1/37, 'From Dr. McCarthy to CS, 7 March, 1935', Anti-Malarial Measures, Zanzibar.

25 ZNA AJ 1/37, 'From Dr. McCarthy to CS, 7 March, 1935', Anti-Malarial Measures, Zanzibar.

26 ZNA BA 7/13, Annual Medical and Sanitary Report for the Year ended 31st December, 1934, p. 13. 
water supply installation to serve the town of Zanzibar. ${ }^{27}$ It was only in the early 1960 s that the tapped water system was sufficient to cover the whole urban population.

Moreover, following MRO recommendations, stone quarrying and the keeping of cattle were totally moved outside Zanzibar Town. The prevention of quarrying in the town was introduced as water retained in these holes permitted mosquitoes to breed. Initially, the decree to stop the digging of holes in the town was enforced in 1929. The decree ordered that "no person shall make or cause to be made any excavation, which is likely to foster the breeding of mosquitoes, on any land within any place which has been or may be declared to be a Town under the Towns Decree 1929 or within two miles of the boundary of any such Town". At that time, the decree did not intend to stop the quarrying of stones in Zanzibar Town.

In 1934, the medical authorities accepted the advice of Dr. McCarthy, that quarrying works which were going on at both the Kikwajuni private and government quarries, behind the house of the Commissioner of Police and throughout the town had to be stopped. Dr. Lee, the Director of Medical Services wrote to the Secretary of the Town Board requesting that a rule to be made under section 79 of the Public Health Decree to prohibit all quarrying for stone or digging inside the town boundary or within a distance of two miles from the town boundary. ${ }^{28}$ In 1935, the colonial authority in Zanzibar introduced laws to stop quarrying within the Town of Zanzibar. ${ }^{29}$

From 1934 effectively, all cattle and goat pens were removed from the town area. It was established that

These animals, driven as they are, backwards and forward from Mji Mpia, cut up all the soft grassy places into a mass of hoof marks which, unless carefully watched after the rain season, soon begin to produce $\mathrm{A}$. Costalis in prodigious number... In many swamps the constant daily driving of herds of cattle backwards and forwards across them while they are still wet, pulps the surface of the ground into a honeycombed mass which will neither dry up quickly nor drain normally. These cattle also caused considerable damage to the drains themselves by breaking down the sides and thus blocking the channel.30

The Parsee Indian community, however, resisted the order. They requested the medical and public health authorities to allow them to keep cattle in the town for

27 ZNA AB 58/29, 'Report from the Zanzibar Government to the Colonial Office', Colonial Development Fund, 1930-1949.

28 ZNA AJ 16/5, 'From MOH to the Secretary of the Town Board, 8-12-1934', Quarrying in the Township of Zanzibar Prohibition, Control, License, for.

29 ZNA AJ 3/17, 'Zanzibar Town Board Meeting, 15 December, 1934', Cattle in the Township of Zanzibar Prohibition for Keeping Re Of.

30 ZNA AJ 16/5, 'From MOH to the Secretary of the Town Board, 8-12-1934', Quarrying in the Township of Zanzibar Prohibition, Control, License, for. 
religious purposes. The medical authority allowed only one cow in total to be kept by their priest. ${ }^{31}$

\section{Vector Control Programmes}

In Zanzibar, the use of chemicals in the control of mosquitoes had started in the early 1910s. The Zanzibar malaria eradication brigade had focused on applying kerosene in order to control larvae breeding of mosquitoes to collections of water. For water in ditches, automatic oilers were employed, using either drip cans or a ball of rags soaked in kerosene, as two of my informants explained to me. Kerosening of ditches and holes worked during the dry season but it was impossible to apply kerosene to flowing rain water. Some successes were nonetheless achieved through a combination of different preventive measures. ${ }^{32}$

The introduction of tiny fishes to eat mosquito larva was applied at the same time as to the use of kerosene. In Zanzibar millions of fish (Haplochilus playfairii) were distributed by the Unit workers in ponds, fountains, mosque tanks and other places where water was kept permanently. ${ }^{33}$ In 1914, larvivorous fish (Gambusia affinis) were introduced into Zanzibar by Dr. W. Mansfield-Aders. ${ }^{34}$ In 1921, gambusias were also introduced by the US Bureau of Fisheries to Spain and later were shipped to Italy in 1924 during the anti-malaria campaigns. While, these fish were able to reduce the multiplication of larva they did not succeeded in eliminating them. ${ }^{35}$ According to Richard Tren, in South Africa it was the introduction in the early twentieth century of larvivorous fish (Gambusia affinis), in combination with various additional anti-malaria programmes, which eventually succeeded in reducing malaria. ${ }^{36}$

From 1934, in attempt to eradicate malarial mosquitoes in Zanzibar, Paris green was applied in ponds in urban surroundings. Since, the 1930s, the Rockefeller Foundation which was involved in anti-malarial projects in the America applied Paris green as larvicide against malarial mosquitoes in Puerto Rico. Paris green (a mixture of diesel oil and copper aceto-arsenite), which was long in use against pests of food crops was first used in malaria control in the 1920s in countries like India, South Africa and Brazil. Although it was much cheaper than oil and non- toxic to

31 ZNA AJ 3/17, 'Zanzibar Town Board Meeting, 15 December, 1934', Cattle in the Township of Zanzibar Prohibition for Keeping Re Of; See also: ZNA AB 2/331, 'Rules on Mosquito Breeding', The Public Health (Prevention of Mosquito-Breeding) Rules, 1935.

32 Interview with Mr. Simai Haji and Mr. Mohammed Ali, two retired health officers, at Mwembeladu and Jang'ombe on 1 August, 2007.

33 ZNA BA 7/2, Public Health Report for the Year 1913, p. 43.

34 ZNA AJ 1/37, 'From DOMS to MRO, 25 October, 1935', Anti-Malarial Measures in Zanzibar.

35 Harrison, Mosquitoes, Malaria and Man, p.186.

36 Richard Tren and Roger Bate, Malaria and the DDT(London, 2001), p. 26. 
animals and fish and could be used on ponds it was abandoned in many parts of the world as it was unable to kill adult mosquitoes which fed below surfaces.

The fight against malaria and malarial-carrying mosquitoes took a new turn after the Second World War with the introduction of dichloro-diphenyl-trichloroethane (DDT). In 1941, Paul Muller, a Swiss, synthesized DDT for use by soldiers in as a safe and efficient insecticide for killing the clothes moth. It was later employed as anti-malarial tool. According to Gordon Harrison, "Britain gave the manufacture of DDT the highest war wartime priority along with radar and penicillin". ${ }^{38}$ Unlike Paris green, DDT was used to kill adult mosquitoes and it stayed for a very long time. According to Webb, "in most areas of seasonal malaria transmission, two applications per year were enough. Where DDT was laid down, the number of new malarial infectious plummeted toward zero". ${ }^{39}$

The spraying of DDT in urban areas began after the Second World War. The Zanzibar Mosquito Brigade staff sprayed DDT in houses and dhows but the DDT spray was unhelpful in the makuti (thatch) huts of Ngambo, since, as Prothero explains, "the insecticide may not cling to reed or grass thatch, or to leaves. On any of these materials the toxic effects are soon lost". ${ }^{40}$ Similarly, in Tanganyika, larvicidal air spraying was first tried in 1945, and DDT was used for residual spraying in houses in $1946 .{ }^{41}$

As mosquito infestation continued to be a problem, private newspapers owned by individual politicians, wealthy merchants and landlords urged the government to take more strong measures to ensure that mosquitoes were eliminated in the islands. In 1950, the editor of Mwongozi wrote an article entitled: 'DDT performs miracle not in Zanzibar'. The editor cites the examples of countries such as Cyprus and British Guiana where several types of anopheles mosquitoes which were the main carrier of malarial viruses had been drastically reduced. He finished his article with the words "but Zanzibar remains where it has been for much too long". ${ }^{4}$

In the early 1950s, the malaria campaigns were linked with other malaria research programmes in East Africa through the East African High Commission. The East African Institute of Malaria and Vector-Borne Diseases at Amani, Tanganyika assisted Zanzibar in the campaigns. The Zanzibar anti-malaria programmes sought advice from the Director of the East African Malaria Unit. In 1951, for instance, Dr. Bagster Wilson, a parasitologist who did research on the health impacts of malaria control measures in north-eastern Tanganyika and south-eastern Kenya, commented that to safeguard the health of the town population, the Zanzibar authorities should put effort into eradicating malaria in rural areas. As a result, "all houses and huts in the first half mile belt outside the Town of Zanzibar were sprayed with DDT-wettable powder. In conjunction with this, mosquito control

37 Harrison, Mosquitoes, Malaria and Man, pp. 186-7.

38 Harrison, Mosquitoes, Malaria and Man, pp. 211 and 218.

39 Webb, Humanity's Burden, p. 160.

40 R. M. Prothero, Migrants and Malaria (London, 1965), p. 18.

41 Clyde, Malaria in Tanzania, p. 45.

42 ZNA NW 12/2, 'DDT performs miracle not in Zanzibar', Mwongozi, 7 July, 1950, p. 1. 
stations were established on the outer and inner side of this treated belt to ascertain the value of the anti-malarial buffer". ${ }^{43}$ In order to determine the effectiveness of methods to destroy the mosquito in the larvae stage, at the special control stations in the town, daily visits were paid for adult mosquito catching. ${ }^{44}$

In 1953, Wilson's advice was that to reduce malaria in the town there should be year-round efforts to deal with adult mosquitoes in three rural districts in Zanzibar. In addition a protective belt extending to a depth of one mile outside the Zanzibar Township boundaries, and running from north to south, was regularly kept under control in order to reduce the number of adult mosquitoes entering the town. ${ }^{45}$ The use of anti-malaria drugs in the suppression of the diseases was carried on throughout colonial period. The next section looks at the distribution of these drugs in Zanzibar.

\section{Drugs and the War against Malaria}

From the early 1900s, quinine increasingly became an important drug for the suppression of malaria. Cinchona or quina-quina bark which is used to make quinine tablets probably originated in the Andes mountains area. For a long time, the indigenous population of Andes had used quina-quina barks to contain fever. By the 1770s, its uses had dramatically increased in Europe, as more Europeans expanded into tropical areas. In the early 1820 , quinine was produced in Western European manufacturing companies. Philip D. Curtin has shown that by the mid 1850, quinine was used by the British soldiers during the conquest of West Africa. He demonstrates for instance that in a campaign in Benin in 1890, malaria attributed to the deaths of British soldiers eighteen times than as among African troops. ${ }^{46}$ In 1897, Professor Robert Koch validated the use of quinine as antimalarial drugs as it destroys malarial parasites in human blood. It also suppresses malaria fever if it is used as prophylactic.

Supplying quinine to colonial populations became a concern for colonial administrations in the early twentieth century, which had not hitherto been the case. The use of quinine was encouraged by the Colonial Office, which supported the malaria prevention approaches proposed by Patrick Manson, a British physician. Manson believed that malaria would be controlled by using mosquito

43 ZNA AJ 28/52, 'From DOMS to Provincial Commissioner, 3 July, 1951', Health Department: Malaria Control and Measures.

44 ZNA BA 7/22, Medical and Sanitary Report for the Year ended 31st December, 1953, p. 10.

45 ZNA BA 7/22, Medical and Sanitary Report for the Year ended 31st December, 1953, p. 10.

46 P. Curtin, 'The White Man's Grave: Image and Reality', Journal of the British Studies, 1(1) (1961), pp. 94-110; P. Curtin, Death by Migration, Europe's Encounter with the Tropical World in the Nineteenth Century (Cambridge, 1995) and P. Curtin, Disease and Empire, The Health of European Troops in the Conquest of Africa (New York, 1998). 
screens, bed nets and regular quinine dosage. Ronald Ross, on the other hand, questioned the use of quinine as a preventive measure, arguing that it all it did was to suppress the disease. Ross prioritized drainage and the use of larvacides to eliminate mosquito breeding sites. ${ }^{47}$ In the event, many countries in Africa, including Zanzibar, adopted a combination of both Manson's and Ross's preventive measures for malaria eradication. Beginning in 1904, the German administration in Tanganyika, adopted a combination of quinine medication and chemical destruction to destroy breeding sites. German physicians in Tanganyika were mostly not convinced that quinine would help to eliminate malaria, as claimed by Professor Koch, an influential German bacteriologist. Koch's researches in Dar es Salaam in 1897 had led him to believe that smaller doses of quinine were effective in treating malaria. ${ }^{48}$

In Zanzibar, quinine tablets were distributed to officers at their work places, to school children in their schools, and in urban and rural areas through local community heads and local leaders, the Masheha. Possibly the use of community leaders and the Masheha were meant to simplify the anti-malarial programmes. There were precedents elsewhere in the British Empire. For instance in Bengal, India, the distribution of anti-malaria tablets through Post Offices and Vaccination Departments had commenced in $1892 .{ }^{49}$ There too, 'native' doctors were used to supply the anti-malarial drugs. The state's decision to use 'native' doctors in this role was prompted by Bengalese resistance, in many cases, to public health campaigns. ${ }^{50}$ Up until the 1950 s, in Dar es Salaam, Tanganyika, quinine tablets were sold at the Post Office. ${ }^{51}$

The Director of the Public Health Department in Zanzibar wrote in the Annual Report of the Department of Health in 1913 that Headmasters, under directive from Medical Officers, distributed quinine to school children twice a week "in the form of the tannate [a salt of tannic acid] made up of chocolate coating". ${ }^{52}$ Though quinine was supplied in schools in major towns and in rural areas, the programme failed to reach its goal as it was found that the medicines caused trouble to empty stomachs. The Department of Health in cooperation with the Department of Education then decided to provide breakfast to school children, while schools decided to introduce vegetable gardens. ${ }^{53}$ From 1910 in Accra, Ghana, quinine with

47 Raymond Dumett, 'The Campaign against Malaria and the Expansion of Scientific Medical and Sanitary Services in British West Africa, 1898-1910', African Historical Studies, 1(2) (1968), pp. 153-197, p. 165.

48 Ann Beck, 'Medicine and Society in Tanganyika, 1890-1930: A Historical Inquiry', The American Philosophical Society, 67(3) (1977), pp. 15-16.

49 Ihtesham Kazi, Malaria in Bengal from 1860-1920: A Historical Study in a Colonial Setting (Unpublished PhD University of Michigan, 1986), p. 78.

50 Arabinda Samanta, Malarial Fever in Colonial Bengal, 1820-1939, Social History of an Epidemic (Kolkata, 2002), p. 14.

51 Ferguson, 'The Political Economy of Health and Medicine in Colonial Tanganyika', p. 331.

52 ZNA 7/2, Public Health Department Report for the Year 1913, p. 43.

53 Interview with Mr. Ali Juma, a retired nurse at Kwahani on 27 July 2007. 
chocolate candy was also distributed in schools. As K. David Patterson shows, however, the programme was not successful as the chocolate did not obscure the bitterness of quinine. School truancies were noted especially on 'quinine day.' Students would apparently also throw away the medicine they received from their teachers. Despite all these problems the Department of Health in Ghana continued to deliver the drugs to school children. ${ }^{54}$

In Zanzibar, from 1913, the Medical Officers of Health supplied quinine tablets at Police Line, Ziwani to European and local soldiers and their families twice weekly. Indian and Arab government staffs posted to rural areas at Mkokotoni and Chwaka were required to take quinine weekly. ${ }^{55}$ The state was plainly determined to see this policy carried out so as not to lose labourers. Officers who refused to take quinine were warned that they "[were] liable to receive no pay if they [were] absent from duty on account of an attack of malarial fever" ${ }^{56}$ The archival records go no further on this point. Possibly the government servants were willing to obey orders.

In 1913 the Assistant District Officer, through the Health Department's officers, began to distribute quinine tablets in rural areas. The 1913 Annual Report of the Department of Health states that "a certain amount of sulphate of quinine in powder was sent to the Assistant District Officer at Mwera [a locality in South District] for distribution to Masheha". ${ }^{57}$ Sundiata notes that this area posed a particular danger to the health of Omani immigrants there. ${ }^{58}$ The medication was sold at one pice (a unit of currency) per packet of five grains. The Health Department also planned to distribute sulphate of quinine to other districts. ${ }^{59}$ The establishment of dispensaries in urban areas, suburbs and rural areas gave an added boost to the distribution of quinine and malaria treatment. By 1910 there were dispensaries at Mkokotoni in North District and at Chwaka in South District. By 1924, dispensaries and hospitals had been built in rural Unguja and Pemba, at Selem, Mbiji, Mahonda, Mangapwani, all in North District, at Kizimkazi in South District, on Unguja Island, and at Wete in Pemba. By 1938, Unguja had thirteen dispensaries and one general hospital in the urban area while Pemba had seven dispensaries and three general hospitals located at Wete, Chake and Mkoani. ${ }^{6}$

Further impetus to quinine distribution to treat, or as prophylactic against, malaria was due to its encouragement by the League of Nations. In the early 1920s, a Malaria Commission of the League of Nations insisted on the administration of quinine to reduce mortality from the disease in a short time. However, quinine

54 K. David Patterson, Health in Colonial Ghana: Disease, Medicine, and SocioEconomic Change, 1900-1955 (Massachusetts, 1981), pp. 35-36.

55 ZNA BA 7/1, Medical and Sanitary Report for the Year 1913, p. 6.

56 ZNA BA 7/2, Public Health Department Report for the Year 1913, p. 43.

57 ZNA 7/2, Public Health Department Report for the Year 1913, p. 43.

58 Ibrahim Sundiata, 'Twentieth Century Reflections on Death in Zanzibar', International Journal of African Historical Studies, 20(1) (1987), pp. 45-60, p. 51.

59 ZNA 7/2, Public Health Department Report for the Year 1913, p. 43.

60 ZNA AJ 12/13, 'Report on Medical Services, 1910-1950', Medical Services Pemba and Zanzibar. 
supply programmes in Zanzibar, like elsewhere in Africa, faced many problems. Many people were not in a position to buy the drugs. As a result, local people continued to depend on their local medicines. People boiled Neem (azadirachta) leaves and bark to treat malaria. According to Mr. Ali Juma, these medicines became widely adopted and replaced quinine in urban and rural areas. ${ }^{61}$ Urban and rural Arabs continued to employ other familiar therapies such as cauterization in order to overcome swellings of the spleen. In 1920, one Medical Officer stated that many Arab children had "numerous round cicatrices over their upper abdomen and spleen region, due to the barbarous habit of cauterizing with hot copper coins to relieve the pain and swellings" ${ }^{62}$ Khalfan Said of Mwera confirmed to me that cauterization was not meant to cure malaria. It was used to reduce the swellings. ${ }^{63}$ Distribution of quinine in colonial Ghana faced similar problems. According to Patterson, "individuals benefited, especially those with some cash, education and access to distribution centres, but except for a relatively few elite Africans, the impact on the public was small, and the long-term results negligible". ${ }^{64}$

In the second half of the 1940s, paludrine, another anti-malaria drugs in tablet form, manufactured in Europe began to be used. ${ }^{65}$ In Zanzibar, Government officials and their families were given a free issue of paludrine, which was also distributed in schools. Bibi Khamisa Abdulla, a sixty-two year housewife who joined Std. 1 at Kikwajuni Girl's School at Ng'ambo in 1955, told me that they used to receive quinine every month in their school. ${ }^{66}$ These anti-malarial tablets helped to reduce death from malaria in combination with other methods.

These anti-malaria programmes had led to high reduction of malaria cases at the government hospitals and dispensaries. Between 1925 and 1934 as the table below shows a number of malaria patients who attended at the hospital and dispensaries at Zanzibar Town in which most of the cases were treated shows a major improvement.

By the late 1950, the anti-malaria programmes that had focused on the environmental engineering and the distribution of drugs had led to the reduction of malaria and the number of people who were diagnosed with malarial fever in Zanzibar. In 1955, $£ 5800$ was voted for the drainage purposes of the remaining areas. The 1956 Annual Medical Report shows that the swamp drainage helped to reduce the mosquito breeding. The anti-larval methods were widely employed. ${ }^{67}$

61 Interview with Mr. Ali Juma, a retired nurse, at Kwahani on 27 July 2007.

62 ZNA BA 7/7, Medical and Sanitary Report for the Year 1921, p. 34.

63 Interview with Mr. Khalfan Said, a local practitioner, at Mwera on 1 August, 2007.

64 Patterson, Health in Colonial Ghana, p. 36.

65 ZNA AJ 18/28, School Clinic, 1913-45, p. 63.

66 Interview with Bibi Khamisa Abdulla at Kikwajuni, 3 December, 2007.

67 ZNA Annual Report Department of Health, 1955, p. 14. 
Table 1. Percentage of the people who were diagnosed with malaria in Zanzibar Town

\begin{tabular}{lc}
\hline Year & Percentage \\
\hline 1925 & 6.75 \\
1926 & 6.27 \\
1927 & 5.33 \\
1931 & 10.1 \\
1932 & 7.59 \\
1933 & 7.76 \\
1934 & 5.63 \\
\hline
\end{tabular}

Sources: Annual Reports Department of Health, 1928, p. 10 and 1934, p. 8.

The reclamation of these former Creek, swampy and old stone quarry areas contributed to the environmental protection. All these former wet areas were transformed into sports grounds. Initially, in 1910s, the 'Mnazimmoja Decree' was passed. The law had allowed the creation of sports activities at the southern part of the former Creek ground. But the lack of enough funds had delayed the reclamation works and the constructions of sports grounds. After the First World War, the Mnazimmoja ground became a center of many games such as football, field hockey, golf and cricket that were played by European, Asian and African communities. ${ }^{68}$ Moreover, by 1930 , other sports grounds at Ziwani and Mwembeladu were created at the former marshes. In 1935, the area at Saateni, which was used for the excavation of sand which was used for the construction of the town harbour, was used as a football and sports field for the Medical and Municipal departments' staff. ${ }^{69}$

The Kikwajuni old quarry area was transformed into sports ground after the Second World War, when Zanzibar became an active member of the Council of East and Central Africa Football Association's (CECAFA) tournament. CECAFA was launched in Nairobi, Kenya in 1926 and it started a first Gossage Cup competition between Kenya and Uganda teams in 1927. In 1948, Zanzibar became a CECAFA tournament member and in 1949 she decided to organize the Gossage Cup competition. The government in Zanzibar requested the sports authorities to construct a stadium ready for the 1949 competition. The Sports Control Board decided that the former Kikwajuni dump to be converted as a sport ground to accommodate the Gossage Cup competitions. ${ }^{70}$ Beginning in 1958, the former swampy areas in Pemba were converted into sports grounds too. Some of these grounds in Pemba included one at Chake and the area which extended from Wete

68 ZNA AE 4/6, Crown Lands, Department, Lease of Old German Tennis Courts to Mnazimmoja Sports Club.

69 ZNA AB 85/3, 'From the Director of Medical Services (DMS) to the Chief Secretary of State (CS), Zanzibar - 9 September, 1935, Re: Football Ground for Medical Staff,' Sports Grounds, September 1935 - September 1955.

70 ZNA AB 12/24a, 'From Sports Association to CS, 24 June and 25 August, 1948,' Sports Association of Zanzibar, 1926-1945. 
Prison to the vicinity of the government offices, the area immediately to the north of Wete Port and the area stretching from Chake Jetty to Madungu. ${ }^{7}$

\section{Conclusion}

From 1957, the World Health Organization (WHO) and the United Nations International Children's Economic Fund (UNICEF) launched an anti-malaria control programmes in Zanzibar, which successfully eliminated the disease. In 1963, during the end of the British rule in Zanzibar malaria infestations was almost zero percent. In the early phase of anti-malaria programmes that I have explained in this paper, to a great instance malaria infestations in the islands had been reduced nearly to sixty-percent. The Medical and Public Health officers decided to apply insecticides and dry most of the anopheles mosquitoes breeding areas in order to control new breeding. Also, they supplied malaria drugs, which in combination of other methods the disease was reduced.

Amina Issa, $\mathrm{PhD}$, is director of the Department of Museum and Antiques in Zanzibar.

71 ZNA AB 39/279, 'From the office of the Senior Commission to P. H. Nightingale, Hon. Financial Secretary,' Recreation Parks, Land - Playing Fields in Pemba, 1958. 


\section{References}

Beck, A., 'Medicine and Society in Tanganyika, 1890-1930: A Historical Inquiry', The American Philosophical Society, 67(3) (1977), pp. 15-16.

Bennett, N., A History of the Arab State of Zanzibar (London, 1978).

Clyde, D., Malaria in Tanzania (London: Oxford University Press, 1967).

Curtin, P., 'The White Man's Grave: Image and Reality', Journal of the British Studies, 1(1) (1961), pp. 94-110.

Curtin, P., Death by Migration, Europe's Encounter with the Tropical World in the Nineteenth Century (Cambridge, 1995).

Curtin, P., Disease and Empire, The Health of European Troops in the Conquest of Africa (New York, 1998).

Curtin, P., "Medical Knowledge and Urban Planning in Colonial Tropical Africa", in Steven Feierman and John Janzen eds., The Social Basis of Health and Healing in Africa (Berkeley, Los Angeles and Oxford, 1992).

Dumett, R., 'The Campaign against Malaria and the Expansion of Scientific Medical and Sanitary Services in British West Africa, 1898-1910', African Historical Studies, 1(2) (1968), pp. 153-197.

Ferguson, D., 'The Political Economy of Health and Medicine in Colonial Tanganyika', in M. H. Y. Kaniki (ed.), Tanzania under Colonial Rule (London, 1980).

Harrison, G., Mosquitoes, Malaria and Man: A History of the Hostilities since 1880 (London, 1978).

Kazi, I., Malaria in Bengal from 1860-1920: A Historical Study in a Colonial Setting (Unpublished PhD University of Michigan, 1986).

Patterson, K., Health in Colonial Ghana: Disease, Medicine, and Socio-Economic Change, 1900-1955 (Massachusetts, 1981).

Prothero, R., Migrants and Malaria (London, 1965).

Samanta, A., Malarial Fever in Colonial Bengal, 1820-1939, Social History of an Epidemic (Kolkata, 2002).

Simpson, W., Report on Sanitary Matters in East African Protectorate, Uganda and Zanzibar (London, 1915).

Sundiata, I., 'Twentieth Century Reflections on Death in Zanzibar', International Journal of African Historical Studies, 20(1) (1987).

Tren, R. and R. Bate, Malaria and the DDT (London, 2001).

Webb, J., Humanity's Burden, A Global History of Malaria (Cambridge, New York, Madrid, Cape Town, Singapore, São Paulo and Delhi, 2009). 